\title{
SPRR2A Gene
}

National Cancer Institute

\section{Source}

National Cancer Institute. SPRR2A Gene. NCI Thesaurus. Code C114896.

This gene plays a role in the differentiation of keratinocytes. 